\title{
Helicobacter pylori vacA and cagA genotypes in patients from northeastern Brazil with upper gastrointestinal diseases
}

\author{
Meyssa Quezado de Figueiredo Cavalcante', Cicero Igor Simões Silva', \\ Manuel Bonfim Braga-Neto', Andréa Bessa Campelo Fialho', André Nunes Fialho', \\ Alzira Maria C Barbosa', Francisco Will Saraiva Cruz', Gifone A Rocha ${ }^{2}$, \\ Dulciene Maria Magalhães de Queiroz ${ }^{2}$, Lucia Libanez Bessa Campelo Braga¹/+
}

Unidade de Pesquisas Clínicas, Universidade Federal do Ceará, Rua Nunes de Melo 1315, 60430-270 Fortaleza, CE, Brasil ${ }^{2}$ Laboratório de Pesquisas em Bacteriologia, Universidade Federal de Minas Gerais, Belo Horizonte, MG, Brasil

Helicobacter pylori causes chronic gastric inflammation and significantly increases the risk of duodenal and gastric ulcer disease and distal gastric carcinoma. In this study, we evaluated the Helicobacter pylori vacA and cagA genotypes in patients from a Brazilian region where there is a high prevalence of gastric cancer. Polymerase chain reaction (PCR) was used to investigate vacA mosaicism and cagA status in the gastric mucosa of $134 \mathrm{H}$. pylori-positive patients, including 76 with gastritis: 28 with peptic ulcer disease and 30 with gastric cancer. The slm1 variant was the predominant vacA genotype observed, whereas the s1 allele was more frequently observed in patients with more severe diseases associated with $\mathrm{H}$. pylori infection [ $p=0.03$, odds ratio $(O R)=5.72,95 \%$ confidence interval $(C I)=1.15-38.60]$. Furthermore, all of the sl alleles were slb. Mixed vacA $\mathrm{ml} / \mathrm{m} 2$ strains were found more frequently in patients with gastric cancer and a cagA-positive status was significantly associated with gastric cancer $(p=0.016, O R=10.36,95 \% C I=1.35-217.31)$. Patients with gastric cancer $(21 / 21,100 \%, p=0.006)$ or peptic ulcers $(20 / 21,95 \%, p=0.02)$ were more frequently colonised by more virulent $\mathrm{H}$. pylori strains compared to gastritis patients $(41 / 61,67.2 \%)$. In conclusion, in the northeastern of Brazil, which is one of the regions with the highest prevalence of gastric cancer in the country, infection with the most virulent $\mathrm{H}$. pylori strains, carrying the cag A gene and $\operatorname{sim} 1$ vacA alleles, predominates and is correlated with more severe $\mathrm{H}$. pylori-associated diseases.

Key words: H. pylori vacA - cagA gastric diseases

Helicobacter pylori is a gastric pathogen that causes chronic gastric inflammation and significantly increases the risk of developing duodenal and gastric ulcer disease, distal gastric carcinoma and gastric lymphoma (Suerbaum \& Michetti 2002). A high level of phenotypic and genotypic diversity is observed among $H$. pylori strains, especially with respect to virulence markers that confer increased pathogenicity to the bacterium (Suerbaum \& Michetti 2002). In the present study, we used molecular methods to evaluate the prevalence of $H$. pylori virulence genes in the gastric mucosa of patients with gastritis, peptic ulcers and gastric carcinoma in Fortaleza, state of Ceará, Brazil, a region with a high prevalence of gastric cancer and H. pylori infections (Motta et al. 2008). We included 134 non-consecutive patients in the study group from Walter Cantídeo University Hospital, who were infected with $H$. pylori strains (30 with gastric cancer, 28 with peptic ulcer and 76 with gastritis) and were undergoing upper gastrointestinal endoscopy or gastric surgery to remove gastric carcinoma. The study was approved by the Ethical Committee of the institution and informed consent was obtained from all included patients.

+Corresponding author: lucialib@terra.com.br

Received 22 September 2011

Accepted 15 February 2012
During upper gastrointestinal endoscopy, five biopsy specimens were obtained for histological evaluation according to the Houston-Updated Sydney System for the classification of gastritis (Dixon et al. 1996). Additionally, two fragments were collected from the antral mucosa for rapid urease testing and for DNA analysis to detect $H$. pylori virulence genes. Gastric mucosa fragments were obtained from tumours from gastric cancer patients, as was normal tissue (collected $5 \mathrm{~cm}$ away from the tumour).

DNA was extracted from the antral gastric specimens using the QIAamp (QIAgen ${ }^{\circledR}$, Hilden, Germany) kit according to the manufacturer's recommendations. The presence of the $H$. pylori-specific ureA gene was evaluated according to a previously reported methodology (Queiroz et al. 2005).

Polymerase chain reaction amplification of the vacA signal sequence and midregion was performed as described previously (Ashour et al. 2002). The H. pylori strains were initially classified as type $\mathrm{s} 1$ or $\mathrm{s} 2$ and $\mathrm{m} 1$ or $\mathrm{m} 2$, and the s1 genotype was further characterised into sla, s1b or s1c variants (Ashour et al. 2002). The $\operatorname{cag} A$ gene was amplified as described previously (Queiroz et al. 2005). Negative and positive controls were included in all reactions. To evaluate associations between the disease and $v a c A$ mosaicism we excluded mixed infections from the analysis. The groups were compared using the two-tailed chi-square or Fisher's exact test. A value of $p$ $\leq 0.05$ was considered significant. 
The H. pylori-specific ureA gene was detected in the gastric mucosa of all patients. Demographic data on the patients and their vacA mosaicism and $\operatorname{cag} A$ status are shown in Table I. Excluding s1/s2 mixed infections, which were observed more frequently $(p=0.054)$ in peptic ulcer $(25 \%)$ than gastritis $(9.2 \%)$ or cancer $(13.4 \%)$ patients, most of the strains carried the s1 vacA genotype was observed in 100 (74.6\%) cases. Among them, 83 strains were further characterised into s1 variants and all of which were slb. The s1 genotype was observed in $72.4 \%, 71.4 \%$ and $83.3 \%$ of the strains obtained from patients with gastritis, gastroduodenal ulcer and gastric cancer, respectively, and tended to be more frequent in gastric cancer patients $(p=0.06)$. When the strains from patients with peptic ulcer and gastric cancer were evaluated together, the difference became significant ( $\mathrm{p}$ $=0.029$, odds ratio $(\mathrm{OR})=5.72,95 \%$ confidence interval $(\mathrm{CI})=1.15-38.60)$. The most virulent vacA s1 allele was highly predominant among the $H$. pylori strains from the northeastern region of Brazil, even in the group of patients without severe diseases associated with $H$. $p y$ - lori infection. Similar findings have been reported in other western countries (van Doorn et al. 1999), but not in southeastern Brazil (Ashour et al. 2002). It has been demonstrated that distinct $H$. pylori vacA $\mathrm{s}$ and $\mathrm{m}$ alleles show a specific geographical distribution (van Doorn et al. 1999). On the Iberian Peninsula and in Latin America, the most frequent $v a c A$ sl allele is $v a c A$ slb (van Doorn et al. 1999, Ashour et al. 2002). Only the vacA slb allele was identified in this study, which is in agreement with the vacA profile of the strains described in southeastern Brazil (van Doorn et al. 1999, Ashour et al. 2002).

The H. pylori $\mathrm{m} 1$ allele was detected in 74 patients, while the $\mathrm{m} 2$ allele was detected in 41 patients. Eight patients expressed both the $\mathrm{m} 1$ and $\mathrm{m} 2$ alleles, without any difference among the groups $(\mathrm{p} \geq 0.27)$. This distribution is similar to that found on the Iberian Peninsula and in other countries in Latin America (van Doorn et al. 1999). Mixed $v a c A \mathrm{~m} 1 / \mathrm{m} 2$ infections were more frequently observed in gastric cancer patients than gastritis patients $(\mathrm{p}=0.007, \mathrm{OR}=15.23,95 \% \mathrm{CI}=1.57-364.10)$, which was also in agreement with other studies (Figueiredo

TABLE I

Patient characteristics and distribution of Helicobacter pylori vacA and $c a g A$ genotypes according to the studied diseases

\begin{tabular}{|c|c|c|c|}
\hline & $\begin{array}{c}\text { Gastritis }(\mathrm{n}=76) \\
\mathrm{n}(\%)\end{array}$ & $\begin{array}{c}\text { Peptic ulcer }(\mathrm{n}=28) \\
\mathrm{n}(\%)\end{array}$ & $\begin{array}{c}\text { Gastric cancer }(\mathrm{n}=30) \\
\mathrm{n}(\%)\end{array}$ \\
\hline Mean age (standard deviation) & $41.6(12.6)$ & $49.7(40.6)$ & $46.8(14.1)$ \\
\hline Female sex & $50(65.9)$ & $15(53.6)$ & $13(43.3)$ \\
\hline$v a c A$ s1 alleles & $55(72.4)$ & $20(71.4)$ & $25(83.3)$ \\
\hline$v a c A$ s2 alleles & $14(18.4)$ & $1(3.6)$ & $1(3.3)$ \\
\hline$v a c A \mathrm{~s} 1 / \mathrm{s} 2$ alleles & $7(9.2)$ & $7(25)$ & $4(13.4)$ \\
\hline$v a c A \mathrm{~m} 1$ alleles & $39(51.3)$ & $19(67.8)$ & $16(53.3)$ \\
\hline$v a c A \mathrm{~m} 2$ alleles & $28(36.8)$ & $7(25)$ & $6(20)$ \\
\hline$v a c A \mathrm{~m} 1 / \mathrm{m} 2$ alleles & $1(1.3)$ & $2(7.1)$ & $5(16.7)$ \\
\hline Non detected $v a c A$ m allele & $8(10.9)$ & $0(0)$ & $3(10)$ \\
\hline $\operatorname{cag} A$-positive & $56(73.7)$ & $26(92.9)$ & $29(96.7)$ \\
\hline $\operatorname{cag} A$-negative & $20(26.3)$ & $2(7.1)$ & $1(3.3)$ \\
\hline
\end{tabular}

TABLE II

Association of Helicobacter pylori vacA and $\operatorname{cag} A$ genotypes according to the studied diseases

\begin{tabular}{|c|c|c|c|c|c|c|}
\hline \multirow[b]{2}{*}{$v a c A$ genotype } & \multicolumn{2}{|c|}{$\begin{array}{l}\text { Gastritis } \\
\text { (n) }\end{array}$} & \multicolumn{2}{|c|}{$\begin{array}{l}\text { Peptic ulcer } \\
\text { (n) }\end{array}$} & \multicolumn{2}{|c|}{$\begin{array}{l}\text { Gastric cancer } \\
\text { (n) }\end{array}$} \\
\hline & $\operatorname{cag} A+$ & $\operatorname{cag} A-$ & $\operatorname{cag} A^{+}$ & $\operatorname{cag} A-$ & $\operatorname{cag} A+$ & $\operatorname{cag} A-$ \\
\hline $\operatorname{s} 1 \mathrm{~m} 1$ & 28 & 7 & 14 & 0 & 16 & 0 \\
\hline $\operatorname{s} 1 \mathrm{~m} 2$ & 13 & 4 & 5 & 1 & 5 & 0 \\
\hline $\mathrm{s} 2 \mathrm{~m} 2$ & 5 & 4 & 1 & 0 & 0 & 0 \\
\hline Mixed infection & 3 & 1 & 6 & 1 & 5 & 1 \\
\hline Positive $(+)$ - negative (-) & 7 & 1 & 0 & 0 & 3 & 0 \\
\hline Total & 56 & 20 & 26 & 2 & 29 & 1 \\
\hline
\end{tabular}


et al. 2001, Ashour et al. 2002). Eleven patients did not exhibit detectable $\mathrm{m}$ alleles. The prevalence of mixed infections by different $v a c A$ genotypes found in this study was similar to that observed in other studies from the Netherlands (van Doorn et al. 1999) and southeastern Brazil (Ashour et al. 2002), but was lower than that observed in Portugal (Figueiredo et al. 2001) and Mexico (Morales-Espinosa et al. 1999). Mixed infections were found more frequently in patients with severe diseases associated with the infection, which may be attributed to microevolution due to intra-host diversification during long-term colonisation (Aras et al. 2003). The s1m1 $v a c A$ genotype was the most common vacA allelic combination observed (Table I), even in the group of patients without the more severe $H$. pylori-associated diseases. This finding was similar to what has been observed in eastern countries (Yamaoka et al. 1999).

The prevalence of $H$. pylori cagA-positive strains varies by geographic region and has been associated with more severe gastroduodenal diseases in some areas (Oliveira et al. 2003). In the present study, a high prevalence of $\operatorname{cag} A$-positive $H$. pylori strains was observed $(82.8 \%)$ (Table I), which was significantly associated with gastric cancer $(\mathrm{p}=0.016, \mathrm{OR}=10.36,95 \%$ $\mathrm{CI}=1.35-217.31$ ), as previously described for patients from different countries and from the southeastern and northeastern regions of Brazil (Evans et al. 1998, Umit et al. 2008, Lima et al. 2011).

Previous studies have also shown associations between a $\operatorname{cag} A$-positive genotype and the presence of peptic ulcers (Evans et al. 1998, Oliveira et al. 2003, Martins et al. 2005, Umit et al. 2008).

In this study, we observed that infection with $\operatorname{cag} A$ positive strains was more prevalent in patients with peptic ulcers than patients with gastritis, but this finding did not achieve statistical significance $(\mathrm{p}=0.06, \mathrm{OR}=4.64$, 95\% CI $=0.94-31.09$ ).

Because the vacA s1 allele was associated with $c a$ $g A$-positive status $(\mathrm{p}=0.02, \mathrm{OR}=5.19,95 \% \mathrm{CI}=1.16$ 23.40) and the vacA s $1 \mathrm{~m} 1$ genotype tended to be observed among $\operatorname{cag} A$-positive strains $(\mathrm{p}=0.08)$ (Table II), we examined whether the $\operatorname{cag} A+v a c A \operatorname{sim} 1$ and $\operatorname{cag} A+$ $v a c A \operatorname{s} 1 \mathrm{~m} 2$ strains, which are the most virulent $H$. pylori strains, were associated with severe $H$. pylori-associated disease by analysing only the strains genotyped for all of the investigated genes and excluding mixed infections. Patients with gastric cancer $(21 / 21,100 \%, \mathrm{p}=0.006)$ and peptic ulcers $(20 / 21,95 \%, p=0.02)$ were more frequently colonised by the most virulent $H$. pylori strains compared to gastritis patients $(41 / 61,67.2 \%)$ (Table II).

In conclusion, in the northeastern region of Brazil, which is the region with the highest prevalence of gastric cancer, infection by the most virulent $H$. pylori strains, carrying the $\operatorname{cag} A$ gene and the slm1 vac $A$ alleles, predominates and is correlated with more severe $H$. pyloriassociated diseases.

\section{REFERENCES}

Aras RA, Lee Y, Kim SK, Israel D, Peek RM Jr, Blaser MJ 2003. Natural variation in populations of persistently colonizing bacteria affects human host cell phenotype. J Infect Dis 188: 486-496.
Ashour AA, Magalhães PP, Mendes EN, Collares GB, de Gusmão VR, Queiroz DM, Nogueira AM, Rocha GA, de Oliveira CA 2002. Genotypes of vacA strains of Helicobacter pylori isolated from Brazilian adult with gastritis, duodenal ulcer or gastric carcinoma. FEMS Immunol Med Microbiol 1412: 1-6.

Dixon MF, Genta RM, Yardley JH, Correa P 1996. Classification and grading of gastritis. The updated Sydney System. International Workshop on the Histopathology of Gastritis, Houston 1994. Am J Surg Pathol 20: 1161-1181.

Evans DG, Queiroz DMM, Mendes EN, Evans DE 1998. Helicobacter pylori cag $A$ status and $\mathrm{s}$ and $\mathrm{m}$ alleles of vacA in isolates from individuals with a variety of $H$. pylori-associated gastric diseases. J Clin Microbiol 36: 3435-3437.

Figueiredo C, Van Doorn LJ, Nogueira C, Soares JM, Pinho C, Figueira P, Quint WG, Carneiro F 2001. Helicobacter pylori genotypes are associated with clinical outcome in Portuguese patients and show a high prevalence of infections with multiple strains. Scand J Gastroenterol 36: 12778-12783.

Lima VP, Silva-Fernandes IJF, Santos KKS, Rabenhorst SHB 2011. Prevalence of Helicobacter pylori genotypes (vacA, cagA, cagE and virb11) in gastric cancer in Brazilian's patients: an association with histopathological parameters. Can Epidemiol 35: e32-37.

Martins LC, Corvelo TCO, Demachki S, Araújo MTF, Assumpção MB, Vilar SCAJ, Freitas FB, Barbosa HPM, Fecury AA, do Amaral RKC, dos Santos SEB 2005. Clinical and pathological importance of $v a c A$ allele heterogeneity and $c a g A$ status in peptic ulcer disease in patients from North Brazil. Mem Inst Oswaldo Cruz 100: 875-881.

Morales-Espinosa R, Castillo-Rojas G, Gonzalez-Valencia G, Ponce de Leon S, Cravioto A, Atherton JC, Lopez-Vidal Y 1999. Colonization of Mexican patients by multiple Helicobacter pylori strains with different $v a c A$ and $c a g A$ genotypes. J Clin Microbiol 37: 3001-3004.

Motta CRA, Cunha MPSS, Queiroz DMM, Cruz FWS, Guerra JCG, Mota RMS, Braga LBC 2008. Gastric precancerous lesions and Helicobacter pylori infection in relatives of gastric cancer patients. Digestion 78: 3-8.

Oliveira AG, Santos A, Guerra JB, Rocha GA, Oliveira AMR, Oliveira CA, Cabral MMDA, Queiroz DMM 2003. BabA2 and cagA positive Helicobacter pylori strains are associated with duodenal ulcer and gastric carcinoma in Brazil. J Clin Microbiol 41: 39643966.

Queiroz DMM, Bittencourt P, Guerra JB, Rocha AM, Rocha GA, Carvalho AS 2005. ILIRN polymorphism and cagA-positive Helicobacter pylori strains increase the risk of duodenal ulcer in children. Pediatr Res 58: 892-896.

Suerbaum S, Michetti P 2002. Helicobacter pylori infection. N Engl JMed 347: 1175-1186.

Umit V, Tezel A, Bukavaz S, Unsal G, Otkun M, Soylu AR, Tucer D, Bilgi S 2008. The relationship between virulence factors of Helicobacter pylori and severity of gastritis in infected patients. Dig Dis Sci 54: 103-110.

van Doorn LJ, Figueiredo C, Mégraud F, Pena S, Midolo P, Queiroz DMM, Carneiro F, Vanderborght B, Pegado MGF, Sanna R, de Bôer W, Schneeberger PM, Correa P, Atherton JC, Blaser MJ, Quint WGV 1999. Geographic distribution of vacA allelic types of Helicobacter pylori. Gastroenterology 116: 823-830.

Yamaoka Y, El-Zimaity HMT, Gutierrez O, Figura N, Kim JK, Kodama T 1999. Relationship between the cagA 3' repeat region of Helicobacter pylori, gastric histology and susceptibility to low pH. Gastroenterology 117: 342-349. 